RAINBOW Vol. 8(1)(2019)
UNNES Journal of Literature, Linguistics and Cultural Studies
http://journal.unnes.ac.id/sju/index.php/rainbow

\title{
An Analysis of The Symbol in Westlife's Song Lyrics
}

\author{
Hanna Eka Rosita ${ }^{\bowtie}$,Bambang Purwanto, Mohamad Ikhwan Rosyidi \\ English Department, Languages and Arts Faculty, Universitas Negeri Semarang, Indonesia
}

\begin{tabular}{|c|c|}
\hline Article Info & Abstract \\
\hline $\begin{array}{l}\text { Article History: } \\
\text { Received } 26 \text { February } 2019 \\
\text { Approved } 25 \text { July } 2019 \\
\text { Published } 29 \text { July } 2019\end{array}$ & $\begin{array}{l}\text { Song is one example of literature. Listening song is enjoyable activity, but the listener } \\
\text { cannot get a pleasure if they do not understand the meaning in the song. Sometimes song } \\
\text { consists of symbol to describe the meaning of a song. Based on the reason, it brought the } \\
\text { researcher to find out the symbol and meaning in the song lyrics and to explain the } \\
\text { impacts of symbol toward real life. This study applied a descriptive qualitative method. } \\
\text { Through this method the researcher tried to analyze, explain, and find out the meaning } \\
\text { of the symbols by using Charles Sanders Pierce's theory. In this case, Charles Sanders } \\
\text { Pierce developed a triadic model in illustrating the definition of the sign as a symbol. The } \\
\text { triadic model consisted of three components; representamen, object and interpretant. The } \\
\text { unit analysis of this study were Westlife's songs, there were more than } 145 \text { songs in } 11 \\
\text { albums. Because of the large amount of the songs, the researcher chose } 7 \text { songs from the } \\
\text { Greatest Album of Westlife that are Swear it Again, If I Let You Go, Flying without } \\
\text { Wings, I Have a Dream, My Love, Uptown Girl, and You Raise Me Up. This study } \\
\text { contained } 5 \text { kinds of symbols that were symbol of color (12 items), symbol of thing (19 } \\
\text { items), symbol of situation (18 items), symbol of sound (5 items), and symbol of } \\
\text { imaginative ( } 7 \text { items). Furthermore, the most dominant symbol was symbol of thing. } \\
\text { Symbols brought some impacts to real life to help the listeners or the readers to } \\
\text { understand the real meaning toward real life. }\end{array}$ \\
\hline
\end{tabular}

(C) 2019 Universitas Negeri Semarang

\footnotetext{
$\triangle$ Corresponding Author

E-mail: hannarosita1995@gmail.com
}

ISSN : 22526323 


\section{INTRODUCTION}

Literature reflects the various experiences, ideas, passions of human beings in their daily life that express on several forms and styles of literary works. One form of literature is song lyric that is a part of the literary work which has the intrinsic elements like poetry. It is expressing a person's personal feelings and thoughts, and connected to written for, singing. It is also a kind of poetry which is generally short and characterized by a musical use of language. It is the name for a short poem, that is usually divided into stanzas and directly expressing the poet's own thoughts or sentiments. It is the word of a song and it is an important part in the creation of a song because song lyric is a tool that can be used to express ideas and feelings of the songwriter.

In reading the song lyric, someone not only read or looked at the words that were lined up in the song lyric but he/she also tries to understand the meaning of the song lyric. The expression of idea in a poem sometimes comes in a form of sign, symbol, icon, or even code. Pierce (in Hawkes 1978: 126-128) that "sign is something for someone to represents something else." Also, there is the 'typology of signs': starting from Pierce's trichotomy are symbols, indices, and icons. Symbol is a mode in which the signifier does not resemble signified but which is fundamentally arbitrary or purely convention. Icon/iconic is a sign whose signifier bears a close resemblance to the thing it refers to. Index/indexical is a mode in which the signifier is directly connected in some ways (physically or causally) to the signified.

Based on the elaboration above, the researcher is interested in conducting a research on analysis symbol in Westlife's song lyrics. The researcher will find the symbols in the lyrics of the songs then classify each of symbols in order to find out the meaning and describe the messages to be conveyed.

With regard to the background of the story above, there are several reasons for choosing this topic. First, Based on the fact of Semiotics, literary work is a (complex) sign system. The sign systems consist of symbol, icon, and index.
Therefore, the researcher wants to analyze the symbol in Westlife's song lyrics. Second, during the popularity of Westlife's songs, which consists of some popular songs and they are still remembered. However, there are some impacts toward real life.

A review of related theories in a general semiotic theory will be considered powerful according to its capacity for offering an appropriate formal definition for every sort of sign-function, whether it has already been described and coded or not. Semiotics is concerned with everything that can be taken as a sign. A sign is everything which can be taken as significantly substituting for something else.

Charles Sanders Pierce / Piercian Semiotics said that there are three sides of sign. The sides are representamen, object and interpretant (Peirce 1940:101). In that book, Peirce says that a sign is something stands for something. Peirce gives a definition of representamen as the sign itself, the object is the thing which is referred, and the interpretant is the product from the connection between interpretant and object. Taking the example above, according to Peirce the word pen is the representamen, yet the object is the pen physically. For the interpretant is what thought which is appeared when someone hears pen, such as "writings", "ink:, "paper", and so on. It means that those sides (Representamen, Object, Interpretant) are something which should always be together. They are inseparable in semiosis because they have their functions to determining each other so that semiosis process can describe or determine the sign clearly.

\section{METHODS}

The research designs used in this study are mixing between descriptive and qualitative study, which merely focuses on the analysis of the textual data. The simplest way to define qualitative study is to say that it is a type of research which involves interpreting no numerical data. The data are the textual data obtained in the song lyrics. According to Creswell (1994: 1) suggested that "a qualitative study is 
designed to be consistent with the assumption of qualitative paradigm."

The object of the study entitled "Swear it Again", "If I let You Go", "Flying without Wings", "I Have a Dream", "My Love", "Uptown Girl", and "You Raise Me Up". There are number-one-tracks during the popularity of Westlife in Ireland and Britain and it is very entertaining.

In gaining the data, first, the researcher was read all the song lyrics and paid more attention to the symbol which is used on it. Second, the researcher was identified the symbol which is found then look for the meaning of the symbol in those lyrics. Third, the researcher was analyzed the lyrics carefully and understanding the figurative language, describe the symbols of the song lyrics, and find out the meaning. Fourth, the researcher crosschecked the analysis of the symbols to the research advisor thus the data were regarded as valid because the data were already approved by an expert in literary analysis

\section{RESULTS AND DISCUSSIONS}

After conducting this research, the researcher conduct five symbol categories; the symbol of color, the symbol of thing, the symbol of situation, the symbol of sound, and the symbol of imaginative visualization (Santoso, 1993:5).

\section{Swear It Again}

The general meaning and symbol of the song entitled Swear it Again tells the readers and listeners about the struggle of The Man to show his seriousness of loving The Girl. The Man will do everything to make The Girl happy and prove to the world that they are completed each other. The symbol represented of the song is Promise. Swear it Again shows the personal style of showing his feeling to the girl that he loves. The man promises to love her through happy and upset, health and sick, bright and dark, ups and downs. Loving the girl is not only brings a joy and happy but also it brings a pain and doubt. Moreover, the man promises the girl to holding hands each other, to face the future together, and make the love stronger. The impact of symbol toward real life is people have to simply make a promise with ourselves to reach the success in study, in career, in family, in some fields surrounding. Then, make a promise with our family for not break their trust to us by not doing bad things. For example: free sex, drugs, smoke, alchohol, and show off the part of body which may not be visible. Afterwards, make a promise with partner for not betray the relationship and always keep the love stronger. Later, make a promise with people surrounding for not heart breaking each other by keeping the spoken, action, behavior, and respect. So, someone can spread love, spread good vibes and life happily.

\section{If I Let You Go}

The general meaning of If I Let You Go tells the readers and listeners about the feeling of worry and scare of losing the love from The Man's life. The Man is very scared if it is all happen in his life, The Man cannot imagine his life without The Girl because he is really love The Girl. The Man would never give up of giving his best to The Girl. The symbol represented of the song is Doubt. If I Let You Go shows the man's depressing and worrying because of too much thinking the negativity. He is doubtful if the girl leaves him someday, on the other hand, he believes the power of their love is unbreakable. The impact of symbol toward real life is someone has to realize about two-sides of live. There are good and bad, happy and sad, up and down, positive and negative, health and sick, also black and white. People should not stuck on one side only, but people have to be balancing the twosides in life. Someone can decrease the negativity by doing more positivity. Thinking the negativity too much can broke himself, so someone should be steady to face the risk that will happen in the future.

\section{Flying Without Wings}

The general meaning of Flying without Wings tells the readers and listeners about someone's believe in something impossible. The Man always thinks positively and never give up on surviving his happiness in life. The symbol represented of the song is Optimism. Flying without Wings shows the confidence to face the 
problems alone and the new hope to motivate him about something better in the future. Imagining something that is impossible is allowed if someone still realized which one is real and which one is fiction. The impact of symbol toward real life is someone has to be optimism of what he has to do. Someone does not have to be surrender before we fight. Also, someone does not need to be so much expecting on someone or something because expecting would hurt himself, and the fact is not as beautiful as what someone's expected before. So, the important thing is someone should be fight for something that makes the dream comes true and reach the happiness.

\section{I Have A Dream}

The general meaning and symbol of the song entitled I have a Dream to motivate the readers and listeners of faced the problems in life and to reach the goals of life. Also, it tells us for always be confidence and optimism to face the future. The symbol represented of the song is Hope. I have a Dream shows the beautiful imagination of person. Everybody is allowed to have a dream because dreaming can motivate us to reach it. By doing some steps or efforts to make the dream comes true. But we have to see the capability to reach which dream that can achieve and which is not. The impacts of symbol toward real life is someone should have to be a motivator for ourselves and be someone else motivator, too. Giving the motivation is easy but applying to the real life is uneasy. It takes time and it needs processes to give a life lesson. The researcher found a quote from Colin Powell "a dream does not become reality through magic; it takes sweat, determination, and hard work" as well as what Winston Churchill said that "success is not final, failure is not fatal: it is the courage to continue that counts" that two quotes mean that we need some efforts, times, and hard work to reach someone's dream.

\section{My Love}

The general meaning of My Love is tells the readers and the listeners about The Man's journey and passion of loving the girl. Having
The Girl makes him happy a whole day, and seeing her smile is The Man's goal in life. The symbol represented of the song is Loyalty. $M y$ Love shows how the man treats the girl and it shows the loyalty. It does not matter how hard to prove and how difficult to make the girl happy a whole day. The impact of symbol toward real life is as the researcher knows that the basic principal to have a relation with other people is loyal. Loyalty is the most important thing that should someone has in personal character because someone does not only have a relation with one or two people. So, someone has to be consistent and loyal to other people.

\section{Uptown Girl}

The general meaning of Uptown Girl tells the readers and listeners about the modesty of The Girl's life style. She looks an old-fashioned but it shows the purity, humility, and loyalty. The symbol represented of the song is simplicity. Uptown Girl shows the modesty, humility, and loyalty of an uptown girl. The lack of the girl does not limit her to show her purity and it makes her look more beautiful just the way she is. The impact of symbol toward real life is as the researcher knows the quote "do not judge book by its cover" it is as well as do not judging people by their appearance. Someone would never know their real character just by seeing their appearance. In this era, someone has to be smart of appreciate someone else. People do not need someone with beautiful make up, beautiful suits, beautiful accessories, and being glamour to cover his/her real character in which fake, arrogant, grudge, and egoist. Moreover, someone should be a simple person, kind hearted, honest, and be yourself. It can make people comfortable and happy be with you as a friend, as a partner, and as a family.

\section{You Raise Me Up}

The general meaning of You Raise Me Up tells the readers and listeners about disaster. As we know this song is made for all tsunami victims in Aceh in 2006, twelve years ago. All of world is grieving at the disaster and Westlife too. This song present the Westlife's cares and supports to 
them, to make them did not to give up because the incident. The symbol represented of the song is strength. You Raise Me Up describe about that victims that so straw because the disaster. They were down and so weary, they get troubles and their heart burdened is. While they can do anything just stay and silent, may they do not know what should they know, until the help come. While the help come they raise them to be strongest than before, face the problem, and do more things than they can do. The impacts of symbol toward real life is we have to be strong of face the problems in life. Someone should be believed that there will be happiness after the sadness, there would be rainbow after rain. Someone needs to be thinking positively because thinking negatively is only breaks the dreams and break the positive minds, too. Also, someone has to be someone that can give someone else's strength to raise up from the down and continue their life.

\section{CONCLUSION}

In the lyrics of Westlife's selected songs contain symbol that is helpful in understanding it. The symbols that have been found are promise, doubt, optimism, spirit and motivation, loyalty, simplicity, and strength.

According to the symbols that have been found in the song, the researcher can conclude that these songs are dominantly told the listeners or the readers about life's struggle and sacrifice. The researcher knows that life is not easy, and life is complicated. So, these songs can be a motivation song to face something in some sides to see a good side and bad side. Moreover, by listening to the song people can see the life experiences and get some moral value inside the song lyrics. Symbols bring some impacts to help the listeners or the readers in understanding the real meaning of the song.

\section{REFERENCES}

Beker, Judith. (1990). "Kalau Bahasa Dapat Diterjemahkan, Mengapa Musik Tidak?" in Jurnal Musikologi Indonesia.
Bressler, Charles E. (1998). Literary Criticism: An Introduction to Theory and Practice. Houghton College: Prentice Hall, Upper Saddle River, New Jersey 07458

Eagleton, Terry. (1943). Literary Theory: An Introduction. London: University of Minnesota Press.

Diyanni, R. (2004). Literature: Approach to Fiction, Poetry and Drama. New York: McGraw Hill Companies.

Eco, Umberto. (1976). A Theory of Semiotics. United States of America: Indiana: University Press.

Faruk. (2012). Metode Penelitian Sastra: Sebuah Penjajahan Awal. Yogyakarta: Pustaka Pelajar.

Hartshorne, Charles, Paul Weiss. (1935). The Collection Papers of Charles Sanders Pierce (ed.). Cambridge: Harvard University Press.

Kennedy, X.J. (1979). Literature: An Introduction to Fiction, Poetry, and Drama. Second Edition. Boston: Little Brown and Company.

Mujiyanto, Yan. (2011). Petunjuk Penulisan Skripsi. Semarang: UNNES Press.

Perrince, Laurence. (1987). Sound and Sense: An Introduction to Poetry. United States of America: Harcourt Brace Jovanovich, Inc.

Pierce, Charles Sanders. (1940). Philosophica Writings of Pierce; Edited by Justus Buchler. New York: Dover Publications, Inc.

Polonsky, Marc. (1958). The Poetry Reader's Toolkit; A Guide to Reading and Understanding Poetry. Colombus: McGraw Hill Companies.

Radvanszky, Aniko. (2010). The Semiotic Perspectives of the Symbol. Peter University.

Riffaterre, M. (1978). Semiotics of Poetry. Bloomington: Indiana University Press.

Saussure, Ferdinand de. (1966). Course in General Linguistics; Translated by Wade Baskin. New York: McGraw Hill Paperback.

Sheriff. Jonk K. (1981). Semiotic Themes; Edited by Richard T. De George with the Charles S. Pierce and the Semiotics of Literature. Lawrence: University of Kansas Publications.

Waluyo, Herman J. (1987). Teori dan Apresiasi Puisi. Jakarta: Erlangga. 